\title{
Estimate of Changes in Carbon Stocks Based on Land Cover Changes in the Leuser Ecosystem Area (LEA) Indonesia
}

\author{
Dedi Hermon \\ Geography Department \\ and Graduate Program State University of Padang Indonesia \\ Corresponding E-mail: dihermon006@gmail.com
}

\begin{abstract}
This research aimed at designing the model of land cover changes in 1990 and 2014, and estimating carbon stock changes in each land cover in Leuser Ecosystem Area (LEA). The spatial model of land cover changes was analyzed by interpreting Landsat 5 TM imagery in 1990 and Landsat 7 ETM+ imagery in 2014 with ERDAS 9.1 and Land Change Modeller (LCM) in Idrisi TerrSet v.18. The analysis of land area changes (ha) in each land cover from 1990 to 2014 used ERDAS 9.1 with tools Interpreter (GIS Analysis-Matrix). Systematic survey method was employed in order to analyze carbon stocks. The sampling technique was stratified purposive composite sampling which used plot technique. The estimate of tree biomass used allometric equation. The estimate of carbon stocks in each land cover in 1990 was measured based on the total of carbon stocks in 2014 which was conversed with the areas of each land cover in 1990. Spatial model of land cover changes in LEA in 1990-2014 showed the changes of area in each land cover which caused the changes of carbon stocks in each land cover as well.
\end{abstract}

Keywords: Leuser Ecosystem Area, Carbon Stocks, Land Cover Change

\begin{abstract}
Abstrak
Tujuan penelitian adalah untuk menyusun model perubahan tutupan lahan tahun 1990 dan 2014 serta melakukan estimasi perubahan cadangan karbon pada setiap tutupan lahan di Leuser Ecosystem Area (LEA). Model spasial perubahan tutupan lahan LEA di analisis dengan melakukan interpretasi Citra Landsat 5 TM tahun 1990 dan Citra Landsat 7 ETM+ tahun 2014 dengan ERDAS 9.1 dan Land Change Modeller (LCM) dalam Idrisi TerrSet v.18. Analisis perubahan luas lahan (ha) pada masing-masing tutupan lahan periode tahun 1990-2014 menggunakan ERDAS 9.1 dengan tools Interpreter (GIS Analysis-Matrix). Analisis cadangan karbon menggunakan metode survey secara sistematis dengan teknik pengambilan sampel adalah stratified purposive komposit sampling dengan menggunakan teknik plot. Adapun pendugaan biomassa pohon menggunakan persamaan allometrik. Penghitungan perkiraan cadangan karbon pada masing-masing tutupan lahan pada tahun 1990 adalah berdasarkan hasil perhitungan karbon pada tahun 2014 yang dikonversikan dengan luasan masingmasing tutupan lahan pada tahun 1990. Model spasial perubahan tutupan lahan di Leuser Ecosystem Area (LEA) periode 1990-2014, menunjukan terjadinya perubahan luas (ha) pada masing-masing tutupan lahan, sehingga mengakibatkan terjadinya perubahan cadangan karbon pada masing-masing tutupan lahan.
\end{abstract}

Keywords: Leuser Ecosystem Area, Carbon Stocks, Land Cover Change

\section{Introduction}

Carbon is closely related to land cover changes because the largest carbon stocks are on forest area. Hermon (2012a) states that carbon stocks in forest land cover are relatively bigger than any other land covers namely shrub, cultivation, and paddy field. Loss of carbon stock happens if land cover of forest, cultivation, and paddy field are changed into settlements which make the dynamics of carbon stock in each land cover are decreasing year by year. Harun (1992); Kustiawan (1997); Pribadi et al. (2006); Hermon (2009); and Hermon (2012a) explain that the changes of land cover are mostly triggered by people economic activities and development which then dominate and impose 
natural areas (forest) to change their function. This condition makes the decreasing of carbon stocks in certain areas which then reduce more carbon stocks every year.

Lusiana et al. (2005); Hermon (2010); Hermon (2012a); and Hermon (2012b) elaborate that carbon has much influence on climate change, and can give negative effect to the earth because $20 \%$ of greenhouse gasses are caused by deforestation or the change of forest areas into another type of land cover. In 2000, it was estimated that the land use emissions, and the changes of land use in Indonesia was 2, $563 \mathrm{Mt} \mathrm{CO}_{2}$ or equal to $20 \%$ of the total emissions of land and forest changes in the world. These emissions were mostly caused by deforestation and forest degradation. Hermon (2014a) explains about the correlation between land cover changes and carbon stocks, and its impact on climate change in Padang. It was explained that the land cover changes of forest, shrubs, cultivation to settlements in Padang from 1985-2011 triggered the increasing of greenhouse gases concentrate especially the increasing amount of $\mathrm{CH}_{4}, \mathrm{CO}_{2}$, and $\mathrm{N}_{2} \mathrm{O}$. The increasing amount of $\mathrm{CO}_{2}$ was caused by forest logging and burning for becoming settlements or other economic activities.

The changes of forest land cover into other types of land cover also happened in Leuser Ecosystem Area (LEA). From 2006 to 2009, there was a decrease of LEA forest area for $\pm 400,00$ ha in Southeast Aceh Regency. This decrease indicated that LEA was having damaged because of the conversion of forest land cover to other types of land cover. The changes that occurred from year to year cause the change of carbon stocks (WWF, 2015). LEA itself is rainforest areas and national parks which consist of swamps, lowland and upland forests, and mountains which are located in two provinces-Aceh and North Sumatra. Geographically, LEA lies between Laut Tawar Lake in Aceh Province and Toba Lake in North Sumatra Province with 2.6 million hectares areas which cover Southeast Aceh Regency, Gayo Lues, Central Aceh, Bener Meriah, Aceh Singkil, Kota Subulussalam,
South Aceh, Southwest Aceh, Nagan Raya, West Aceh, Aceh Tamiang, East Eceh, North Aceh, Langkat, Dairi, Karo and Deli Serdang. According to its geomorphological areas, LEA has slopes from flat to very steep ones, with the rainfall between 2500-4000 mm/year. LEA has the biggest biodiversity in Asia, so that it has many ecological functions such as water reserve, climate stabilization, mitigation of erosion and flash floods, prevention of pest outbreaks, and carbon stocks (Forestry Department and IFCA, 2007; WWF, 2015; Hermon 2014b; Hermon, 2014c).

LEA has significant role for keeping the stability of earth temperature and climate; thus, LEA functions as National Park, and is also determined as Biosphere reserves by UNESCO. Threat of LEA sustainability is the conversion of land to become agricultural land (cultivation and paddy field), plantation, and settlements for people living around LEA. This land conversion will change forest land cover into agricultural and residential land cover in which this condition will directly change the carbon stocks in LEA (TFCA Sumatera, 2015). The change of carbon stocks are analyzed based on the change of land cover by combining analysis technique of remote sensing imagery and field survey to measure above ground biomass. The objective is to formulate the spatial model of LEA land cover changes as guidance in estimating carbon stock from 1990 to 2014.

\section{Research Method}

\section{Spatial Model of Land Cover Changes in Leuser Ecosystem Area (LEA)}

The model of land cover change is analyzed based on Zain (2002); Hermon (2009); and Hermon (2012a) by interpreting Landsat 5 TM 1990 imagery and Citra Landsat 7 ETM+ 2014 (path row 130-58) with ERDAS 9.1 as the analysis tool. The classification of land cover change is analyzed with supervised classification technique for each image which resulted on six temporary patterns of land cover, namely (1) forest, (2) cultivation, (3) 
paddy field, (4) shrub, (5) plantation, (6) settlement, and (7) body of water. Before classifying land cover by using supervised classification technique, separability analysis in the form of quantitative analysis is carried out in order to inform us the evaluation of separated areas in each class as a validation of band combination using ENVI 4.5 (Hermon, 2009). The analysis of land cover change is conducted by using Land Change Modeller (LCM) Idrisi TerrSet v.18. Meanwhile, the analysis of land area change (hectares) in each land cover in 1990 and 2014 is conducted by using ERDAS 9.1 with tools Interpreter (GIS Analysis-Matrix).

\section{The Analysis of Carbon Stock Change in Leuser Ecosystem Area (LEA)}

The analysis of carbon stock in each land cover is carried out by using Above Ground Biomass (AGB) technique with systemic survey method. Sampling technique used is stratified purposive composite sampling with plot technique (Hairiah and rahayu, 2007; Hermon, 2012a). The plot size for taking the sample of trees is $10 \mathrm{x} 10 \mathrm{~m}$; meanwhile $1 \mathrm{x} 1 \mathrm{~m}$ of plot size which is made in each land cover is used for taking the sample of undergrowth and litter (Hermon, 2012a). The samples of trees (stalks, branches, twigs, and leaves) are taken compositely and analyzed with nondestructive method; meanwhile the samples of undergrowth and litter are analyzed with destructive method. The estimate of tree biomass uses allometric equation (Kattering, 2001) with BKis 0.11 p D2.62 in which D is the diameter of tree at breast height, $\mathrm{cm}$ ) and $\mathrm{p}$ is the density of wood. The biomass of undergrowth and litter is measured based on the total dry weight per quadrant (in gr/ $\mathrm{m} 2$ and conversed to ton/ha) which uses the formula: Total of BK (gr) = BK/BB x total of $\mathrm{BB}$ (gr), in which BK (dry weight, gr) and BB (wet weight, gr). The total of carbon stocks is got from the total of biomass multiplied with 0.46 ( the concentrate of $\mathrm{C}$ in organic materials is about 46\%) (Hairiah and Rahayu, 2007; Hermon, 2012a). The estimate of carbon stocks in each land cover in 1990 was based on the estimate of carbon stocks in 2014 which was conversed with the areas of each land cover in 1990 (Hermon, 2012a).

\section{Result and Discussion}

\section{Spatial Model of Land Cover Change in Leuser Ecosystem Area (LEA)}

The analysis using Landat 5 TM imagery in 1990 and Citra Landsat 7 ETM+ imagery in 2014 resulted on the data of land cover changes for the last 24 years, between 1990 and 2014 . Spatial model of land cover change in LEA from 1990 to 2014 can be seen in Picture 1 below. The spatial model of land cover change in LEA from 1990 to 2014 informed us that land cover for settlements was increasing in 2014 compared to 1990; on the other hand, land cover of forest in 2014 as well as land cover of cultivation, plantation, and shrub was relatively decreasing compared to 1990 . The increasing of land cover area for paddy field occurred in 2014 compared to 1990. Baban and Yusof (2001); Amdam (2004); and Antrop (2004) explain that spatial model of land cover change will give the information spatially about all variation of land cover changes. 


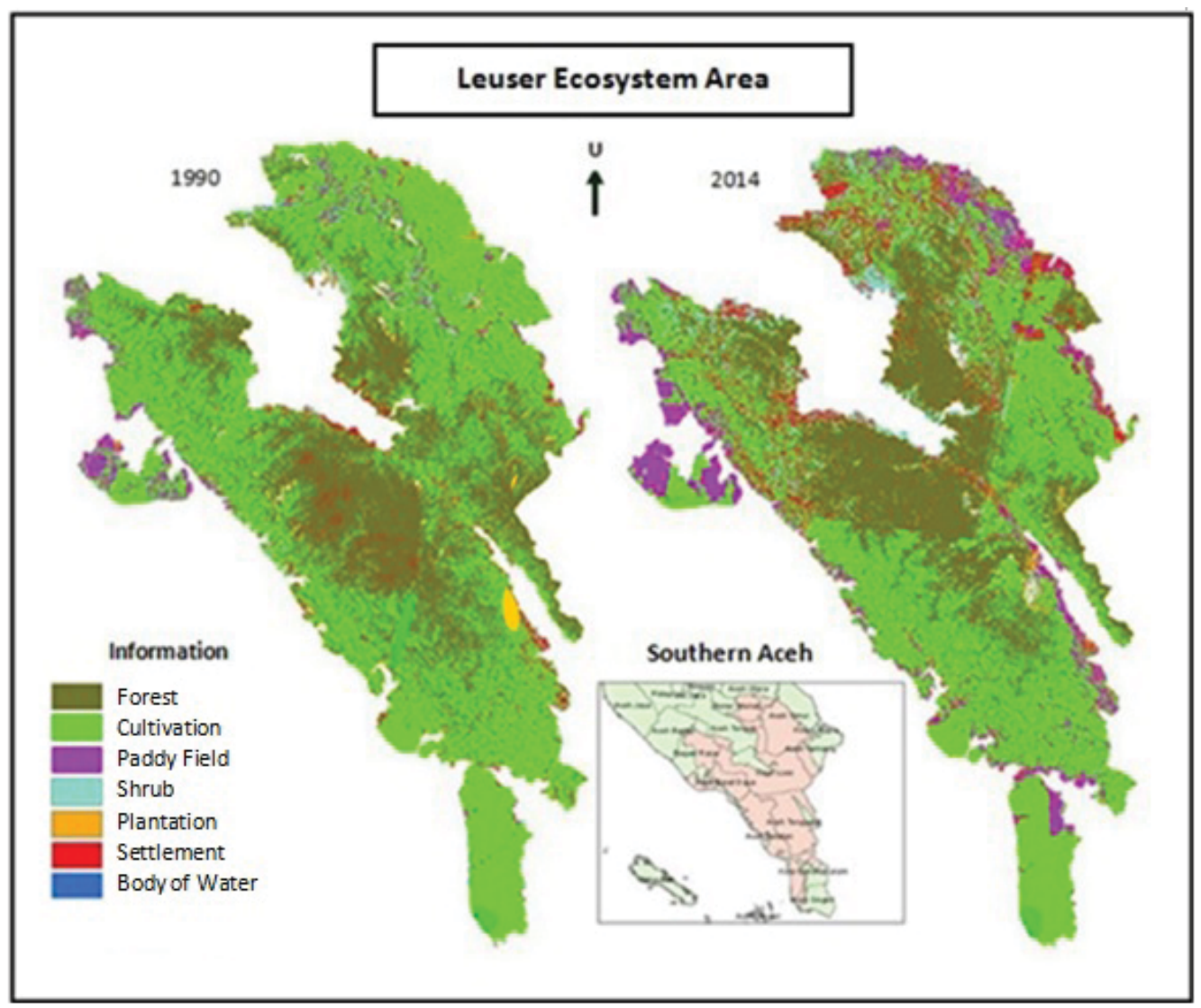

Figure 1. Spatial Model of Land Cover Change in The Leuser Ecosystem Area (LEA) 1990 and 2014

The variation of land cover changes in LEA increasing of settlements in LEA indicate that in 1990 and 2014 was caused by the activities of people surrounding LEA, such as for enhancing settlements, for new paddy field area, or other economic activities (TFCA, 2015). The reduction of forest area and the 2015).

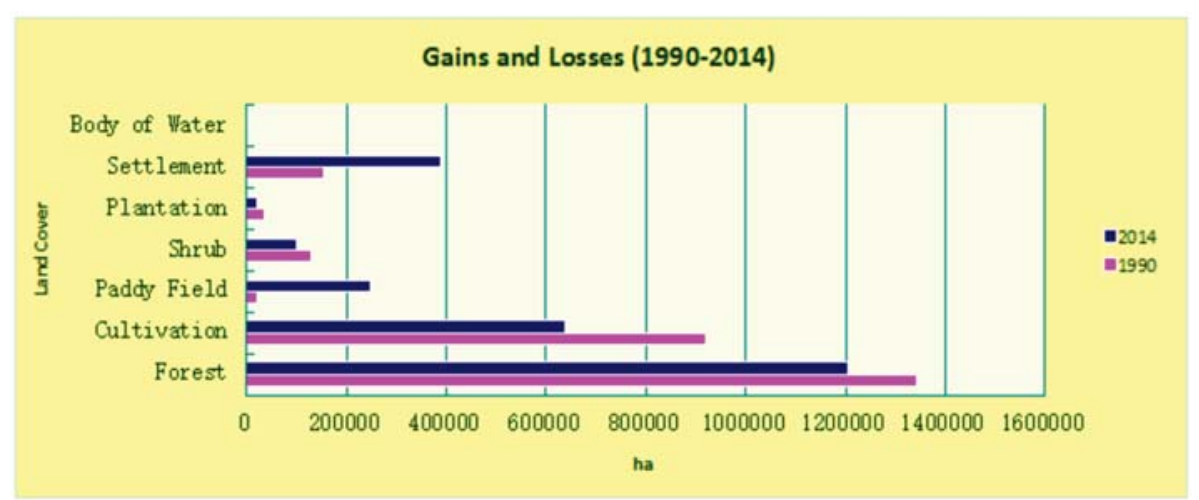

Figure 2. Gains and Losses Land Cover Area in The Leuser Ecosystem Area (LEA) in Year Period 1990-2014 
The data reveal that in 1990 the area of forest in LEA was 1,341,322.1 ha; cultivation was 920,528.3 ha; settlement was 153,231.1 ha; and the body of water was 1,576.1 ha. Compared to 2014, there was changes in each land cover in which the area of forest was decreasing into 1,205,576.2 ha; cultivation was decreasing into 638,331.1 ha; paddy field was increasing into 247,319.1 ha; shrub was decreasing into 99,098.1 ha; plantation was decreasing into 19,333.2 ha; and settlement was increasing into 388,766.3 ha; meanwhile, there was no change on the body of water which was 1.576.1 ha. Chust et al (2004) conveys that no changes in the body of water in certain period of time indicate that the changes of land cover are mostly oriented on agriculture and new settlements. Furthermore, Hermon (2012a) elaborates that land cover changes into agriculture (paddy field, cultivation) and settlements have big influence on the changes and loss of carbon stocks. The decreasing of carbon stocks happen if there is a conversion of land cover of forest to agricultural area, and the loss of carbon stocks happen when land cover of forest, paddy field, and shrub is conversed into settlements

Table 1. Land Cover Change in the Leuser Ecosystem Area (LEA) in Year Period 1990-2014

\begin{tabular}{|c|c|c|c|c|c|}
\hline \multirow[t]{2}{*}{ No } & \multirow[t]{2}{*}{ Land Cover } & \multirow{2}{*}{$\begin{array}{l}1990 \\
\text { (ha) }\end{array}$} & \multirow{2}{*}{$\begin{array}{l}2014 \\
\text { (ha) }\end{array}$} & \multicolumn{2}{|c|}{$\begin{array}{l}\text { Extensive Changes in Land Cover } \\
\text { (ha) }\end{array}$} \\
\hline & & & & Increase & Reduce \\
\hline 1 & Forest & 1.341.322,1 & $1.205 .576,1$ & 0 & $135.746,0$ \\
\hline 2 & Cultivation & $920.528,3$ & 638.331,1 & 0 & $282.197,2$ \\
\hline 3 & Paddy Field & $19.113,0$ & 247.319,1 & 228.206,1 & 0 \\
\hline 4 & Shrub & $128.575,3$ & $99.098,1$ & 0 & $29.477,2$ \\
\hline 5 & Plantation & $35.654,1$ & $19.333,2$ & 0 & $16.320,9$ \\
\hline 6 & Settlement & 153.231,1 & $388.766,3$ & $235.535,2$ & 0 \\
\hline 7 & $\begin{array}{l}\text { Body of } \\
\text { Water }\end{array}$ & $1.576,1$ & $1.576,1$ & 0 & 0 \\
\hline & Total & 2.600 .000 & 2.600 .000 & 463.741,3 & 463.741,3 \\
\hline
\end{tabular}

Source: Result of GIS Matrix Analysis of Landsat 5 TM 1990 and Landsat 7 ETM+ 2014 using ERDAS 9.1 and LCM Idrisi TerrSet v.18 (2015)

In the period of 1990-2014, there were many changes of land cover areas into settlements such as forest areas which became settlements for 98,254.3 ha, cultivation area becoming settlements for 132,380.1 ha, paddy field area becoming settlements for 876.1 ha, shrub area becoming settlements for 578.5 ha, and the changes of plantation areas becoming residential areas for 3,445.2 ha.

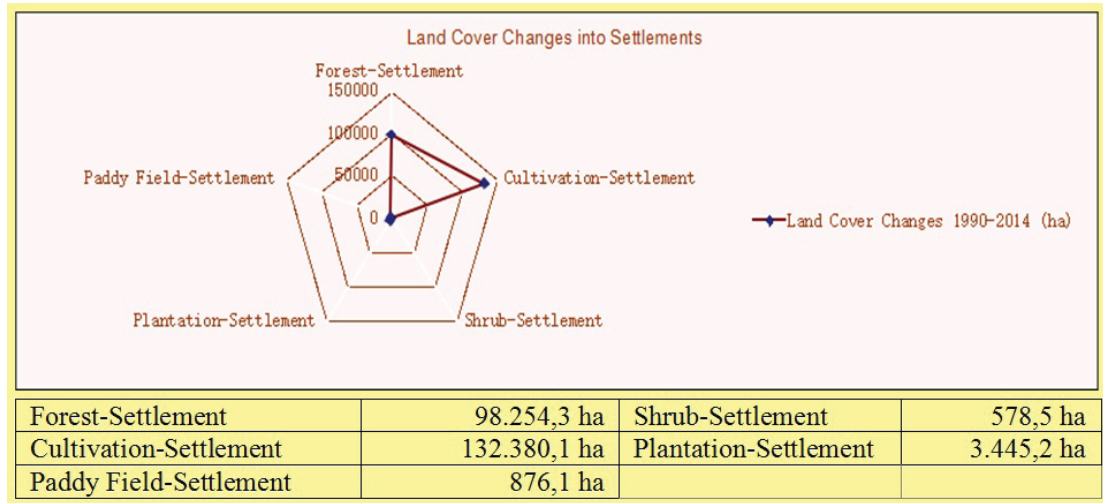

Figure 3. Land Cover Changes into Settlements in The Ecosystem Area (LEA) Period 1990-2014 
Fitzsimmons (2003); Lubowski et al. (2006); Ritohardoyo (2007); Hermon (2009); and Hermon (2012a) explain that land cover changes especially the changes of land cover of forest into settlements will continue to occur and always spatially varied either planned or unplanned. Dahroni (2008) states that settlement will always be a source of problem in human history since the development of settlements will cause the uncontrollable land cover changes, particularly on the changes of land cover of forest into other land covers related to settlements and economic activities.

\section{The Estimate of Carbon Stock Changes in Each Land Cover lin Leuser Ecosystem Area (LEA)}

The changes of forest, cultivation, paddy field, shrub, and plantation areas into settlements in LEA from 1990 to 2014 indicated the change of carbon stocks in LEA. For more detail, it is shown in Table 2 below.

Table 2. Biomass and Carbon Stocks in the Leuser Ecosystem Area (LEA) in 2014

\begin{tabular}{|c|c|c|c|c|c|c|c|}
\hline \multirow[b]{2}{*}{ Land Cover } & \multirow{2}{*}{$\begin{array}{c}\text { Trees } \\
\text { Number/ } \\
\text { ha }\end{array}$} & \multicolumn{2}{|c|}{ Tree Biomass } & \multicolumn{2}{|c|}{ Litter Biomass } & \multirow{2}{*}{$\begin{array}{c}\text { Total Bio- } \\
\text { mass } \\
\text { (ton/ha) }\end{array}$} & \multirow{2}{*}{$\begin{array}{l}\text { Carbon } \\
\text { (ton/ha) }\end{array}$} \\
\hline & & $\left(\mathrm{kg} / \mathrm{m}^{2}\right)$ & (ton/ha) & $\left(\mathrm{kg} / \mathrm{m}^{2}\right)$ & $\begin{array}{c}\text { (ton/ } \\
\text { ha) }\end{array}$ & & \\
\hline Forest & 341 & 365,22 & $3.652,20$ & 18,320 & 183,20 & $3.835,40$ & $1.764,28$ \\
\hline Cultivation & 57 & 15,77 & 157,70 & 15,44 & 154,40 & 312,10 & 146,56 \\
\hline Paddy Field & 0 & 0,00 & 0,00 & 19,89 & 198,90 & 198,90 & 91,26 \\
\hline Shrub & 16 & 2,87 & 28,70 & 26,93 & 269,30 & 298,00 & 137,08 \\
\hline Plantation & 239 & 64,84 & 648,40 & 7,11 & 71,10 & 719,50 & 330,97 \\
\hline Settlement* & -- & -- & -- & -- & -- & -- & -- \\
\hline Body of Water* & -- & -- & -- & -- & -- & -- & -- \\
\hline Total & 653 & 448,70 & 4487,00 & 87,69 & 876,90 & $5.363,90$ & $2.470,15$ \\
\hline
\end{tabular}

Source: Data Analysis Research, 2015

Based on the condition in 2014, the carbon stocks per hectare in LEA was 2,470.15 ton/ ha which spread on forest area for $1,764.28$ ton/ha, paddy field for 91.26 ton/ha, shrub for
137.08 ton/ha, and plantation for 330.97 ton/ ha. The total of carbon stocks in 2014 in LEA is presented in Table 3 below.

Table 3. Total Carbon Stocks in The Leuser Ecosystem Area (LEA) 2014

\begin{tabular}{lccc}
\hline \multicolumn{1}{c}{ Land Cover } & Area (ha) & Carbon Stocks (ton/ha) & Total Carbon Stocks (ton) \\
\hline Forest & $1.205 .576,1$ & $1.764,28$ & $2.126 .973 .801,70$ \\
Cultivation & $638.331,1$ & 146,56 & $93.553 .806,01$ \\
Paddy Field & $247.319,1$ & 91,26 & $22.570 .359,31$ \\
Shrub & $99.098,1$ & 137,08 & $13.584 .367,54$ \\
Plantation & $19.333,2$ & 330,97 & $6.398 .874,68$ \\
Settlement* & $388.766,3$ & -- & -- \\
Body of Water* & $1.576,1$ & -- & -- \\
\multicolumn{1}{c}{ Total } & 2.600 .000 & $2.470,15$ & $2.263 .081 .209,24$ \\
\hline
\end{tabular}

Source: Data Analysis Research, 2015

* Not Analyzed

In 2014, the total of carbon stocks in LEA was $2,263,081,209.24$ ton which spread on forest area for 2,126,973,801.70 ton, cultivation for 93,553,806.01 ton, paddy field for $22,570,359.31$ ton, shrub for $13,584,367.54$ ton, and plantation 6,398,874.68 ton. The biggest carbon stocks were in the forest so that the preservation of forest area must be sustainable. The conversion result of carbon stocks in LEA in 1990 can be seen in Table 4. 
Table 4. Prediction of Total Carbon Stocks in the Leuser Ecosystem Area (LEA) 1990

\begin{tabular}{lccc}
\hline \multicolumn{1}{c}{ Land Cover } & Area (ha) & $\begin{array}{c}\text { Carbon Stocks Predic- } \\
\text { tion (ton/ha) }\end{array}$ & $\begin{array}{c}\text { Prediction of Total carbon } \\
\text { Stocks (ton) }\end{array}$ \\
\hline Forest & $1.341 .322,1$ & $1.764,28$ & $2.366 .468 .283,87$ \\
Cultivation & $920.528,3$ & 146,56 & $134.912 .686,27$ \\
Paddy Field & $19.113,0$ & 91,26 & $1.744 .252,38$ \\
Shrub & $128.575,3$ & 137,08 & $17.625 .102,13$ \\
Plantation & $35.654,1$ & 330,97 & $11.800 .437,48$ \\
Settlement* & $153.231,1$ & -- & - \\
Body of Water* & $1.576,1$ & -- & -- \\
\multicolumn{1}{c}{ Total } & 2.600 .000 & $2.470,15$ & $2.532 .550 .762,13$ \\
\hline
\end{tabular}

Source: Data Analysis Research, 2015

* Not Analyzed

Based on the conversion result of carbon stocks, it was known that the carbon stocks in LEA in 1990 were 2,532,550,762.13 ton. In details, forest areas had the carbon stocks for 2,366,468,283.87 ton, cultivation for 134,912,686.27 ton, paddy field for
1,744,252.38 ton, shrub for $17,625,102.13$ ton, and plantation for $11,800,437.48$ ton. In the period of 1990-2014, there was decrease and increase of carbon stocks on each land cover, as shown in Table 5.

Table 5. Decrease and Increase Carbon Stocks on Each Land Cover in the Leuser Ecosystem Area (LEA) Period 1990-2014

\begin{tabular}{lcccccc}
\hline Land Cover & $\begin{array}{c}\text { Area (ha) } \\
1990\end{array}$ & $\begin{array}{c}\text { Prediction of Total } \\
\text { Carbon Stocks (ton/ } \\
\text { ha) }\end{array}$ & $\begin{array}{c}\text { Area (ha) } \\
2014\end{array}$ & $\begin{array}{c}\text { Total Carbon } \\
\text { Stocks (ton) }\end{array}$ & $\begin{array}{c}\text { Decrease in } \\
\text { Carbon Stocks } \\
\text { (ton) }\end{array}$ & $\begin{array}{c}\text { Increse } \\
\text { (ton) }\end{array}$ \\
\hline Forest & $1.341 .322,1$ & $2.366 .468 .283,87$ & $1.205 .576,1$ & $2.126 .973 .801,70$ & $239.494 .482,17$ & 0,0 \\
Cultivation & $920.528,3$ & $134.912 .686,27$ & $638.331,1$ & $93.553 .806,01$ & $41.358 .880,26$ & 0,0 \\
Paddy Field & $19.113,0$ & $1.744 .252,38$ & $247.319,1$ & $22.570 .359,31$ & 0,0 & $20.826 .106,93$ \\
Shrub & $128.575,3$ & $17.625 .102,13$ & $99.098,1$ & $13.584 .367,54$ & $4.040 .734,59$ & 0,0 \\
Plantation & $35.654,1$ & $11.800 .437,48$ & $19.333,2$ & $6.398 .874,68$ & $5.401 .562,80$ & 0,0 \\
Settlement* & $153.231,1$ & -- & $388.766,3$ & -- & -- & - \\
Body of Water* & $1.576,1$ & -- & $1.576,1$ & -- & -- & - \\
\multicolumn{1}{c}{ Total } & 2.600 .000 & $2.532 .550 .762,13$ & 2.600 .000 & $2.263 .081 .209,24$ & $290.295 .659,82$ & $20.826 .106,93$
\end{tabular}

Source: Data Analysis Research, 2015

* Not Analyzed

The decrease of carbon stocks in LEA in 1990-2014 occurred in forest land cover $(239,494,482.17$ ton), cultivation (41,358,880.26), shrub $(4,040,734.59$ ton), and plantation (5,401,562.80 ton). On the contrary, the increase of carbon stocks occurred in land cover of paddy field $(20,826,106.93$ ton) because land cover of paddy field was increasing in 2014 for 228,206.1 ha. The loss of carbon stocks in LEA because of the changes of land cover into settlements from 1990 to 2014 was quite big; it was 194,049,235.370 ton. In details, the loss of carbon stocks because of land cover changes into settlements can be seen in Table 6. 
Table 6. Loss of Carbon Stocks in Leuser Ecosystem Area (LEA) because of Land Cover Changes into Settlements

\begin{tabular}{llcc}
\hline No & \multicolumn{1}{c}{ Land Cover Change } & Area (ha) & Losses of Carbon Stocks (ton) \\
\hline 1 & Forest-Settlement & $98.254,3$ & $173.348 .096,404$ \\
2 & Cultivation-Settlement & $132.380,1$ & $19.401 .627,456$ \\
3 & Paddy Field-Settlement & 876,1 & $79.952,886$ \\
4 & Shrub-Settlement & 578,5 & $79.300,780$ \\
5 & Plantation-Settlement & $3.445,2$ & $1.140 .257,844$ \\
& & $235.534,2$ & $194.049 .235,370$ \\
\hline
\end{tabular}

Source: Result of GIS Matrix Analysis of Landsat 5 TM 1990 and Landsat 7 ETM 2014 using ERDAS 9.1 and LCM Idrisi TerrSet v.18 (2015) and Data Analysis Research (2015)

In the period of 1990-2014, there were many changes of land cover areas into settlements in LEA such as forest areas which became settlements for $98,254.3$ ha. It means that the loss of carbon stocks in forest area was $173,348,096,404$ ton. The cultivation area becoming settlements was for 132,380.1 ha, which indicated $19,401,627,456$ ton of $1,140,257.844$ ton.

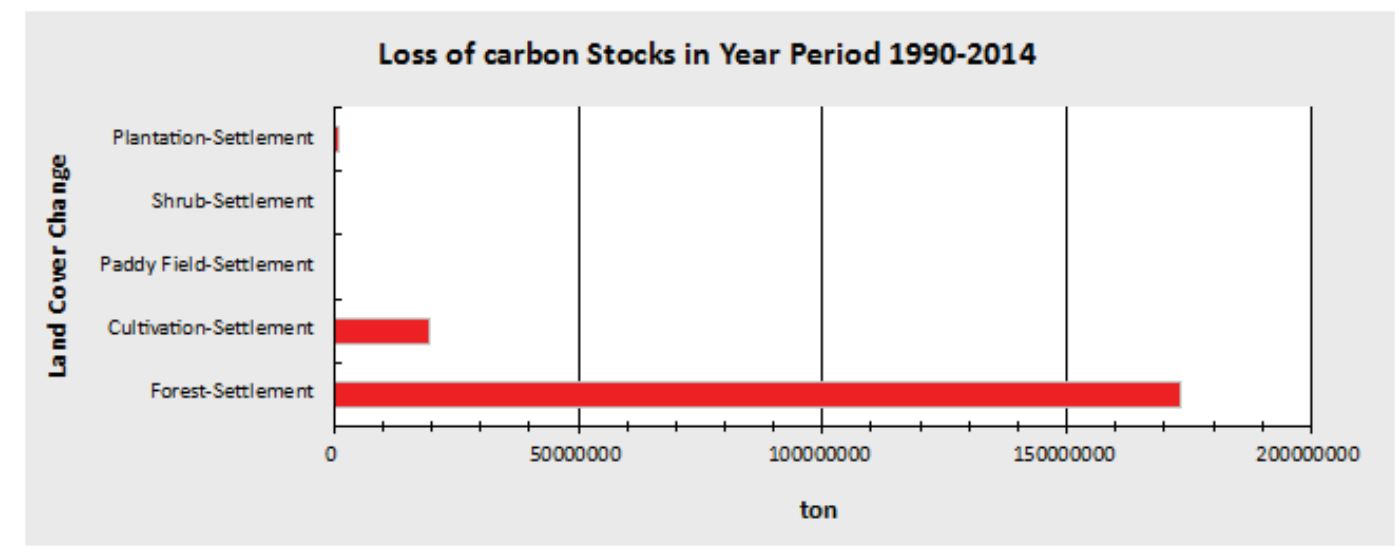

Figure 4. Carbon Loss in The Leuser Ecosystem Area (LEA)

It was found that the biggest carbon stock loss in LEA happened because of the land cover changes of forest areas into settlements for 173,348,096.404 ton from 1990 to 2014. Hermon (2012a) explains that the loss of carbon stocks was triggered by land cover changes into settlements which kept increasing through conversion of forest, shrub, and paddy field carbon stock loss. The land cover changes also occurred in paddy field area in which it became settlements for 876.1 ha which means $79,952,886$ ton carbon stock loss. Then, the changes of plantation areas becoming residential areas were for 3,445.2 ha, and it indicated the loss of carbon stocks for 


\section{Conclusion}

Land cover changes occurred because of people activities which are related to economy and settlements. The changes of land cover will directly change the amount of carbon stock in an area. From 1990-2014, there was a big change of land cover happened in LEA. Land cover of paddy field and settlements were increasing a lot in 2014; meanwhile, land cover of forest, cultivation, shrub, and plantation was decreasing in 2014. In addition, the changes of land cover becoming settlement were the changes dominantly happened in LEA compared to other land cover. This condition caused the decrease of carbon stocks in LEA in 2014 compared to carbon stocks in 1990 for each land cover. The big changes of either land cover of forest or other land covers into settlements had cause the loss of carbon stocks in LEA for 194,049,235.370 ton from 1990 to 2014.

\section{References}

Antrop, M. (2004). Landscape Change and the Urbanization Process in Europe. Landscape and Urban Planning. 67: 9-26. www.elsevier.com/landurbplan

Amdam, R. (2004). Spatial County Planning as a Regional Legitimating Process. European Journal of Spatial Development. 11: 1-22 http://www.nordregio.sc/ EJSD

Baban, S.M., and K.W. Yusof. (2001). Mapping Land Use/Cover Distribution on a Mountainous Tropical Island Using Remote Sensing and GIS. International Journal of Remote Sensing. 22: $1909-1918$

Chust, G., D. Ducrot, and J.L.I. Pretus. (2004). Land Cover Mapping with Patch-Derived Landscape Indices. Landscape and Urban Planning 67: 45-53. www.elsevier.com/locate/ landurbplan

Dahroni. (2008). Analisis Keruangan terhadap Perubahan dan Persebaran Permukiman Kumuh di Kecamatan Banjarsari Kota Surakarta Tahun 2001-2005. Forum Geografi. Vol. 22. No. 1. Juli 2008: 85-96

Fitzsimmons, M. (2003). Effects of Deforestation and Reforestation on Landscape Spatial Structure in Boreal Saskatchewan, Canada.Forest Ecology and Management. 174: 577592. www.elsevier.com/locate/foreco

Departemen Kehutanan dan IFCA. (2007). REDDI, Reducing Emissions from Deforestation and Forest Degradation in Indonesia, REDD Methodology and Strategies Summary for Policy Makers. Dephut. Jakarta

Hairiah, K dan Rahayu, S. (2007). Pengukuran "Karbon Tersimpan” di Berbagai Macam Penggunaan Lahan. Bogor. World Agroforestry Centre - ICRAF, SEA Regional Office, University of Brawijaya, Unibraw, Indonesia.

Harun, U.R. (1992). Dinamika Penggunaan Sumberdaya Lahan di Jawa Barat 1970-1990. Jurnal PWK. 3: 48-53

Hermon, D. (2009). Dinamika Permukiman dan Arahan Kebijakan Pengembangan Permukiman pada Kawasan Rawan Longsor di Kota Padang. Disertasi. IPB Bogor

Hermon, D. (2010). Geografi Lingkungan: Perubahan Lingkungan Global. UNP Press. Padang

Hermon, D. (2012a). Dinamika Cadangan Karbon akibat Perubahan Tutupan Lahan menjadi Lahan Permukiman di Kota Padang Sumatera Barat. Forum Geografi. Vol. 26. No. 1, Juli 2012: 29-44

Hermon, D. (2012b). Mitigasi Bencana Hidrometeorologi: Longsor, Banjir, Degradasi Lahan, 
Ekologi, Kekeringan, dan Puting Beliung. UNP Press. Padang

Hermon, D. (2014a). Impacts of Land Cover Change on Climate Trend in Padang Indonesia. Indo J. Geog. Vol. 46. No. 2: 104-209

Hermon, D. (2014b). Arahan Mitigasi Bencana Longsor Kawasan Gunung Padang Kota Padang Sumatera Barat. Jurnal Geografi. Vol. 3. No. 2: 1-93

Hermon, D. (2014c). Geografi Bencana Alam. Radja Grafindo Persada Press. Jakarta

Ketterings, Q.M., Coe R., Meine van Noordwijk., Ambagau Y., Palm C.A. (2001). Reducing Uncertainty in the of Allometric Biomass Equation for Predicting Aboveground Tree Biomass in Mixed Secondary Forest. Forest Ecology and Management 146: 199-209

Kustiawan, I. (1997). Permasalahan Konversi Lahan Pertanian dan Implikasinya terhadap Penataan Ruang Wilayah. Studi Kasus: Wilayah Pantura Jawa Barat. Jurnal PWK. 8: 49-60

Lubowski, R.J., S. Bucholtz., R. Claassen., M.J. Roberts., J.C. Cooper., A. Gueorguieva., and R. Johansson. (2006). Environmental Effects of Agricultural Land-Use Change. The Role of Economics and Policy. A Report from the Economic Research Service. USDA. www. ers.usda.gov

Lusiana, Betha., Meine van Noordwijk., Surbekti Rahayu. (2005). Cadangan Karbon di Kabupaten Nunukan Kalimantan Timur: Monitoring Secara Spasial dan Pemodelan. ICRAF. Bogor

Pribadi, D.O., D. Shiddiq, dan M. Ermyanila. (2006). Model Perubahan Tutupan Lahan dan Faktor-Faktor yang Mempengaruhinya. Jurnal Teknologi Lingkungan. Pusat Pengkajian dan Penerapan Teknologi Lingkungan. 7: 35-51

Ritohardoyo, S. (2007). Perubahan Permukiman Pedesaan Pesisir Kabupaten Gunung Kidul Daerah Istimewa Yogyakarta Tahun 1996-2003. Forum Geografi. Vol. 21. No. 1. Juli 2007: 78-92

TFCA-Tropical Forest Coservation Action-Sumatera. (2015). Program Restorasi dan Konservasi Kawasan 13 Bentang Alam Prioritas di Sumatera. TFCA Sumatera. Jakarta

WWF. (2015). Deforestation, Forest Degradation, Biodiversity Loss and $\mathrm{CO}_{2}$ Emissions in Sumatra, Indonesia. WWF Indonesia Technical Report. Jakarta.

Zain, A.F.M. (2002). Distribution, Structure dan Function of Urban Green Space in Southeast Asian Mega-Cities with Special Reference to Jakarta Metropolitan Region (JABOTABEK). Doctoral Degree Program. Department of Agricultural and Environmental Biology Graduate School of Agricultural and Life Sciences. The University of Tokyo. Japan 